\title{
Effect of nuclear export inhibition on estrogen receptor regulation in breast cancer cells
}

\author{
Denis Nonclercq, Fabrice Journé ${ }^{1}$, loanna Laïos ${ }^{2}$, Carole Chaboteaux ${ }^{1}$, \\ Robert-Alain Toillon ${ }^{2}$, Guy Leclercq ${ }^{2}$ and Guy Laurent
}

\begin{abstract}
Laboratory of Histology and Experimental Cytology, Faculty of Medicine and Pharmacy, Université de Mons-Hainaut, Pentagone 1B-Avenue du Champ de Mars 6, B7000 Mons, Belgium

${ }^{1}$ Laboratory of Endocrinology-Bone Diseases and ${ }^{2}$ Laboratory J-C Heuson of Breast Cancer Research, Department of Internal Medicine, Institut Jules Bordet, Université Libre de Bruxelles, Rue Heger-Bordet 1, B1000 Brussels, Belgium
\end{abstract}

(Requests for offprints should be addressed to G Laurent; Email: guy.laurent@umh.ac.be)

(D Nonclercq and F Journé contributed equally to this study)

\begin{abstract}
We used the Crm1 inhibitor leptomycin B (LMB) to examine a possible involvement of nuclear export in estrogen receptor $\alpha(E R)$ level and function in MCF-7 breast carcinoma cells. As revealed by immunofluorescence microscopy and western blotting with anti-ER antibodies, LMB produced an accumulation of ER in cell nuclei. LMB also partly abrogated ER elimination resulting from $\mathrm{Hsp} 90$ disruption and $17 \beta$-estradiol $\left(\mathrm{E}_{2}\right)$-induced $\mathrm{ER}$ downregulation. By contrast, it was ineffective on ER downregulation caused by the pure anti-estrogen fulvestrant. Finally, LMB inhibited $E_{2}$-induced progesterone receptor expression and the expression of an estrogen response element-driven luciferase reporter gene in unstimulated and $E_{2}$-stimulated cells. Altogether, the data reported here suggest that: i) ER undergoes nuclear export directly or indirectly involving exportin Crm1; ii) degradation of unliganded and of agonist-bound ER probably occurs in an extranuclear compartment, while it is not the case for ER bound to a pure anti-estrogen; and iii) optimal ER-mediated gene transactivation seems to require nucleocytoplasmic shuttle of the receptor.
\end{abstract}

Journal of Molecular Endocrinology (2007) 39, 105-118

\section{Introduction}

There is a general consensus that the mitogenic action of estrogen hormones is of prime importance in the etiology and the progression of breast carcinoma (Ciocca \& Fanelli 1997, Clarke et al. 2004, Platet et al. 2004). Estrogens exert their effects on target cells through cognate receptors, of which two sub-types (estrogen receptors $\alpha$ and $\beta$, ERs) have been identified in mammals. As revealed by previous work (Gustafsson \& Warner 2000), ER $\beta$ is the dominant form expressed in normal breast tissue. However, breast tumorigenesis is accompanied by a decrease of this latter isoform, in parallel with an increase of ER $\alpha$ (Bardin et al. 2004). Thus, the growth stimulatory effect of estrogens on ER-expressing breast carcinomas (more than two third of breast malignancies, Early Breast Cancer Trialists' Collaborative Group 1998) is considered to be principally mediated by ER $\alpha$ (henceforth referred to as ER).

The intracellular distribution of ER in target cells is complex, accounting for the fact that estrogens, like other steroid hormones, can trigger nongenomic (transcription-independent), as well as genomic (transcription-dependent) responses (Segars
\& Driggers 2002, Lösel et al. 2003, Bjornstrom \& Sjoberg 2005). In the former case, estrogens have been shown to exert their action via membranebound form(s) of ER capable of interacting with various signal transduction pathways (Kelly \& Levin 2001, Levin 2001, Watson et al. 2002, Evinger \& Levin 2005). On the other hand, the genomic effects of ER are mediated by intracellular receptors functioning as ligand-modulated transcription factors (White \& Parker 1998, Aranda \& Pascual 2001, Gruber et al. 2004, O'Lone et al. 2004).

Direct visualization of ER tagged with the green fluorescent protein in transfected living cells reveals that the receptor is mostly nuclear (Htun et al. 1999, Stenoien et al. 2000, Kawata et al. 2001). This has been confirmed by fluorescence microscopy immunolocalization of ER in breast carcinoma cells (Laïos et al. 2003, 2005, Journé et al. 2004, Nonclercq et al. 2004). Yet, it must not be inferred from these observations that ER is sequestered within the nucleus since it has been demonstrated that nuclear hormone receptors undergo dynamic shuttling between nuclear and cytoplasmic compartments (Maruvada et al. 2003).

The intracellular distribution of nuclear receptors (and of other proteins undergoing nucleocytoplasmic 
shuttling) results from a dynamic equilibrium between nuclear entry and exit (reviewed by Shank \& Paschal 2005, Leclercq et al. 2006). As illustrated by studies on the glucocorticoid receptor (GR), receptor translocation into the nucleus involves retrograde transport along microtubules, followed by importin-mediated nuclear entry (reviewed by Pratt et al. 2004). Conversely, receptor exit from the nucleus relies on exportins such as Crm1 (reviewed by Pemberton \& Paschal 2005). The activities of both importins and exportins are coordinated by the small GTPase protein Ran. The discovery of the Crm1 inhibitor leptomycin B (LMB) has significantly contributed to the unraveling of the mechanism of protein nuclear export (Kau \& Silver 2003). Indeed, LMB specifically hinders Crm1 interaction with a nuclear export signal (NES) contained within many proteins undergoing nucleocytoplasmic shuttling. While Crm1 involvement in nuclear export has been definitely established for a number of proteins (e.g. p53, see Results), the situation is less clear for nuclear receptors that do not exhibit classical NES. Indeed, observations reported by Liu \& DeFranco (2000) failed to reveal an activity of LMB on GR nuclear export. On the other hand, a more recent study (Itoh et al. 2002) showed that GR exit from the nucleus was partially blocked by this inhibitor.

In breast carcinoma cell lines characterized by a high expression of ER (e.g. MCF-7, IBEP-2), the steady-state level of the receptor is mostly determined by modulation of its degradation rate (Journé et al. 2004, Laïos et al. 2003, 2005). As shown by studies employing specific inhibitors (El Khissiin \& Leclercq 1999; Alarid et al. 1999, 2006; Lonard et al. 2000; Journé et al. 2004; Laïos et al. 2005), ER breakdown involves the ubiquitinproteasome pathway. Modalities of ER degradation can, however, vary according to the receptor conformation, which is itself determined by the ligand-binding status and/or interactions with partner proteins (Nonclercq et al. 2004, Tateishi et al. 2004). ER stability depends on many factors, such as post-translational modifications, interactions with other proteins (i.e. Hsp90), or the binding of cognate ligands (i.e. estrogen agonists and antagonists; see Discussion in Laïos et al. 2003). ER degradation results in receptor downregulation and contributes to an adjustment of the cell response to estrogenic stimulation.

While the mechanisms involved in ER commitment to proteasomal degradation and the role of the latter process in ER-mediated gene transactivation have been under extensive investigation (Nawaz \& O'Malley 2004, Calligé \& Richard-Foy 2005, Dennis \& O’Malley 2005), comparatively little attention has been paid to a possible compartmentalization of the system(s) responsible for ER elimination. The issue was addressed in the present study by investigating the impact of LMB on ER distribution, downregulation, and transactivation activity in MCF-7 breast carcinoma cells.

\section{Materials and methods}

\section{Drugs and inhibitors}

17ß-estradiol $\left(\mathrm{E}_{2}\right)$, 4-hydroxy-tamoxifen (OH-Tam), and MG-132 were obtained from Calbiochem-Novabiochem (La Jolla, CA, USA). ICI 182780 (fulvestrant) was supplied by Tocris Cookson (Bristol, UK). Radicicol came from Sigma-Aldrich. LMB was purchased from LC Laboratories (Woburn, MA, USA). The raloxifene analog LY 117018 (Schafer et al. 2001) was a kind gift from Eli Lilly \& Co. Stock solutions of these compounds were prepared at least 1000 -fold more concentrated in ethanol and stored at $-20{ }^{\circ} \mathrm{C}$.

\section{Cell culture}

Routine cell propagation and experimental studies were carried out at $37^{\circ} \mathrm{C}$ in a cell incubator with humid atmosphere at $5 \% \mathrm{CO}_{2}$. Unless specified otherwise, cells were cultured in T-flasks containing Dulbecco's Modified Essential Medium (DMEM, Cambrex, Verviers, Belgium) supplemented with Phenol Red, $10 \%$ fetal bovine serum (FBS, HyClone, Logan, UT, USA), $25 \mathrm{mM} N$-2-hydroxyethylpiperazine- $N{ }^{\prime}$-2-ethanesulfonic acid (HEPES), $2 \mathrm{mM}$ L-glutamine, $100 \mathrm{U} / \mathrm{ml}$ penicillin G, $100 \mu \mathrm{g} / \mathrm{ml}$ streptomycin, and $0.25 \mu \mathrm{g} / \mathrm{ml}$ amphotericin B (DMEM-FBS; supplements from Cambrex or Gibco-Invitrogen, Merelbeke, Belgium). Before treatment with drugs and inhibitors, Phenol Red-free DMEM supplemented with $10 \%$ charcoalstripped FBS (HyClone), $25 \mathrm{mM}$ HEPES, and $2 \mathrm{mM} \mathrm{L}-$ glutamine (estrogen-free medium, EFM) was substituted for DMEM-FBS and cells were grown in this medium for a minimum of 2 days.

\section{Western blot analysis}

MCF-7 cells were plated in $60 \mathrm{~cm}^{2}$ Petri dishes at a density of $10^{4}$ cells $/ \mathrm{cm}^{2}$ in EFM and cultured for $24 \mathrm{~h}$. They were subsequently incubated with drugs and/or inhibitors, alone or in combinations, following protocols specified in figure legends. Cell monolayers were rinsed twice with TBS $(50 \mathrm{mM}$ Tris- $\mathrm{HCl} \mathrm{pH} 7.5$ and $150 \mathrm{mM} \mathrm{NaCl}$ ) and harvested using $500 \mu \mathrm{l}$ lysis buffer (TBS containing $0.5 \%$ sodium deoxycholate, $1 \%$ Nonidet P-40, $0 \cdot 1 \%$ SDS, $50 \mathrm{mM}$ NaF, $0.1 \mathrm{mM}$ $\mathrm{Na}_{3} \mathrm{VO}_{4}$, and $5 \mathrm{mM}$ EDTA) with freshly added protease inhibitors. Protein concentrations of total cell lysates were determined by the BCA Protein Assay (Pierce Chemicals Co., Rockford, IL, USA), using BSA as standard. Total cell lysates were mixed with standard 
electrophoresis sample buffer. Denatured samples and molecular weight protein markers (Precision Plus Protein Standards, Bio-Rad) were resolved by $10 \%$ SDS-PAGE under reducing conditions. Proteins were subsequently electrotransferred onto a nitrocellulose membrane (Amersham Pharmacia Biotech, Roosendaal, The Netherlands). The membrane was then incubated for $3 \mathrm{~h}$ at room temperature in a blot solution (10 mM Tris- $\mathrm{HCl} \mathrm{pH} 8,150 \mathrm{mM} \mathrm{NaCl}, 0 \cdot 05 \%$ Tween 20 and $7 \%$ skim milk) to block non-specific binding and then incubated overnight in a fresh blot solution containing a mouse monoclonal anti-human ER $\alpha$ antibody (F-10, Santa Cruz Biotechnology, Santa Cruz, CA, USA) diluted 1:5000 or mouse monoclonal antibodies raised against human progesterone receptor (PgR, both A and B forms; NCL-PGR-AB, Novocastra, Newcastle upon Tyne, UK) diluted 1:500. Actin (used as a loading control) was demonstrated with a mouse antiactin monoclonal antibody diluted 1:7500 (Chemicon, Temecula, CA, USA). Immunoblots were then incubated for $2 \mathrm{~h}$ at room temperature in a blot solution containing peroxidase-conjugated sheep anti-mouse immunoglobulin G ( $\mathrm{IgG}$ ) antibody diluted 1:5000 (Amersham Pharmacia Biotech). Bound peroxidase activity was revealed using the SuperSignal West Pico Chemiluminescent Substrate (Pierce Chemicals Co). The signal associated with immunoreactive material was detected with a LAS-3000 CCD camera (Fujifilm, Düsseldorf, Germany) and the software Image Reader (Raytest, Straubenhardt, Germany). Immunoreactive band intensity was quantified using the software AIDA Image Analyser 3.45 (Raytest).

\section{Immunofluorescence studies}

MCF-7 cells in EFM were plated at a density of $10^{4}$ cells $/ \mathrm{cm}^{2}$ on sterile round glass coverslips in 12-well dishes. Two days after seeding, cells were fed fresh EFM containing drugs and/or inhibitors at the concentrations specified in the figure legends. After the treatment duration specified in the figure legends, cell monolayers were rinsed with Dulbecco's PBS and fixed for 15 min with $4 \%$ paraformaldehyde (PAF) in DPBS. After fixation, PAF was changed for DPBS where the cell cultures were kept at $4{ }^{\circ} \mathrm{C}$ until immunostaining which was performed within the next $20 \mathrm{~h}$.

Demonstration of ER by immunofluorescence was achieved as detailed in a previous publication (Brohée et al. 2000). In short, cell monolayers were rinsed several times with PBS $\left(0.04 \mathrm{M} \mathrm{Na}_{2} \mathrm{HPO}_{4}, 0.01 \mathrm{M} \mathrm{KH}_{2} \mathrm{PO}_{4}\right.$, $0 \cdot 12 \mathrm{M} \mathrm{NaCl}, \mathrm{pH} 7 \cdot 2$ ). In order to ensure cell permeabilization, $0 \cdot 1 \%$ Triton X-100 was included in buffer used for incubations and rinses. Before exposure to primary antibodies, cells were preincubated for $20 \mathrm{~min}$ in PBS containing $0.05 \%$ casein (PBS-CAS) and $0.05 \mathrm{M} \mathrm{NH}_{4} \mathrm{Cl}$ to prevent non-specific adsorption of immunoglobulins. p53 was demonstrated with a mouse monoclonal anti-p53 antibody (Ab-6, Oncogene Merck Eurolab). As primary reagents for ER immunofluorescence staining, we used rabbit polyclonal antibodies raised against residues 2-184 (H-184) in the N-terminal region or residues 576-595 (HC-20) in the C-terminal region of human $\mathrm{ER} \alpha$ (Santa Cruz Biotechnology). Cells were exposed to the primary antibody diluted 1:50 in PBS-CAS. Thereafter, the cell preparations were successively exposed to a dextran polymer conjugated with both peroxidase and antibodies raised against mouse or rabbit immunoglobulins (EnVision, Dakopatts, Glostrup, Denmark), rabbit anti-peroxidase antiserum (Laboratory of Hormonology, Marloie, Belgium), biotinylated swine anti-rabbit immunoglobulins antibodies (Dakopatts), and finally Texas Red-conjugated streptavidin (Vector Laboratories, Burlingame, CA, USA). After final rinses in PBS, the coverslips were mounted on glass slides using commercial anti-fading medium (Vectashield, Vector Laboratories). Negative controls were produced by omitting the primary antibody. This modification resulted in a virtual disappearance of the signal.

The cell preparations were examined on a Leitz Orthoplan microscope equipped with a Ploem system for epi-illumination. Excitation wavelength of $560 \mathrm{~nm}$ and emission wavelength of $590 \mathrm{~nm}$ were used for the observation of Texas Red fluorescence. Image acquisition and analysis were performed as described in a previous publication (Jacquot et al. 2007). Median fluorescence intensities were computed from the analysis of $\sim 80-120$ nuclei in each control or treated culture.

\section{Measurement of ER degradation kinetics}

MCF-7 cells were plated in $60 \mathrm{~cm}^{2}$ Petri dishes $\left(6 \times 10^{5}\right.$ cells per dish). After 3 days of culture, they were fed fresh MEM devoid of L-methionine (Invitrogen) and kept in that medium for $2 \mathrm{~h}$. Protein labeling was achieved by a $2 \mathrm{~h}$ exposure to $10^{-8} \mathrm{M}\left[{ }^{35} \mathrm{~S}\right]$ methionine. At the end of the isotope incorporation period, the labeling medium was replaced by regular medium containing $2 \times 10^{-8} \mathrm{M} \mathrm{LMB}$ (chase) or not.

At different time intervals during the chase period, cell monolayers were rinsed twice with TBS $(50 \mathrm{mM}$ Tris- $\mathrm{HCl} \mathrm{pH} 7.5$ with $150 \mathrm{mM} \mathrm{NaCl}$ ) at room temperature. All further steps were run at $4{ }^{\circ} \mathrm{C}$. Cells were lyzed, using $500 \mu \mathrm{l}$ lysis solution (TBS pH 7.5, 0.5\% deoxycholic acid, $1 \%$ Nonidet P-40, $0 \cdot 1 \%$ SDS, $50 \mathrm{mM} \mathrm{NaF}$, $1 \mathrm{mM} \mathrm{Na} \mathrm{VO}_{4}$, and $5 \mathrm{mM}$ EDTA) containing freshly added proteolysis inhibitors phenylmethylsulphonyl fluoride $(0.6 \mathrm{mM})$ and L-1-tosylamido-2-phenylethyl chloromethyl ketone (TPCK, $0.3 \mathrm{mM}$ ); they were maintained in contact with this solution for $15 \mathrm{~min}$ and then scraped. Lysates were harvested in microtubes and passed four times through a $1 \mathrm{ml}$ syringe fitted with 
a $0.4 \times 19 \mathrm{~mm}$ needle, followed by additional $15 \mathrm{~min}$ incubation, and finally clarified by centrifugation at $17530 \mathrm{~g}$ for $30 \mathrm{~min}$. Protein concentration of such supernatants was measured in an aliquot using the BCA protein assay from Pierce using BSA as standard.

Clarified supernatants containing equivalent amounts of proteins were distributed in microtubes $(600 \mu \mathrm{l})$, incubated with $50 \mu \mathrm{l}$ anti-rabbit IgG agarose for $2 \mathrm{~h}$ under agitation and centrifuged to remove proteins that may non-specifically cross-react at time of immunoprecipitation. Supernatants were incubated overnight with $2 \mu \mathrm{g}$ rabbit anti-ER polyclonal antibody (HC-20; Santa Cruz Biotechnology). ER-antibody complexes were precipitated with $50 \mu \mathrm{l}$ anti-rabbit IgG agarose $(2 \mathrm{~h})$ and agarose-bound complexes were collected by centrifugation and washed four times with $750 \mu \mathrm{l}$ TBS containing detergents $(0.5 \%$ sodium deoxycholate, $1 \%$ Nonidet P-40, 0.1\% SDS). Pellets were suspended in $50 \mu \mathrm{l}$ loading buffer (LDS Sample $4 \times$ buffer from Invitrogen) and boiled for $5 \mathrm{~min}$ to release ER. Such denatured ER samples were stored at $-80^{\circ} \mathrm{C}$ for assessment of ER labeling.

Denatured ER samples were submitted to electrophoresis on $4-12 \%$ polyacrylamide gels ( $75 \mathrm{~mA}$ for two gels). Gels were then successively fixed (acetic acid $10 \%$, methanol $40 \%$, distilled water $50 \%$ ), washed with distilled water, incubated in an ethanolic solution of salicylic acid (to increase the radioactive signals), and finally dried. Radiolabeled ER bands $(67 \mathrm{kDa})$ onto the gels were identified by autofluorography (3 days at $-80{ }^{\circ} \mathrm{C}$ with hyperfilm MP, Amersham Biosciences).

\section{Estrogen response element (ERE)-dependent tran- scriptional activity}

In order to assess the transactivation capacity of ER, assays were run on MVLN cells (MCF-7 cells stably transfected with a pVit-tk-Luc reporter plasmid; Pons et al. 1990). ER-mediated transcription of the reporter gene was evaluated by measuring induced luciferase activity (Demirpence et al. 1993) using the Luciferase Assay System from Promega. Cells were plated in 6-well plates at a density of $10^{5}$ cells / dish in EFM, cultured for 3 days, and then incubated with drugs and/or inhibitors at the concentrations specified in figure legends. At the end of treatment, the medium was removed and cell monolayers were rinsed twice with PBS. Diluted lysis solution $(250 \mu \mathrm{l}$, Promega E153A) was added to the cultures, which were submitted to mild agitation for $20 \mathrm{~min}$ in order to extract luciferase. Detergent-lysed cells were scraped and suspensions were clarified by centrifugation $(5 \mathrm{~min}, 10000 \mathrm{~g}$ ). Finally, $20 \mu \mathrm{l}$ extracts were mixed at room temperature with $100 \mu$ l luciferase reagent mixture (Promega E151A/ E152A), prepared according to the manufacturer's protocol. Luminescence was measured in a Lumat LB 9507 luminometer (Berthold Technologies, Bad Wildbad, Germany). Luciferase induction was expressed in arbitrary units (relative luciferase units, RLU) calculated per milligram of protein, and data are given as percentages of the mean value obtained from untreated cells.

\section{Protein determination}

Protein concentrations in total cell lysates obtained by detergent extraction were determined by the BCA Protein Assay (Pierce) using BSA as standard.

\section{Statistical analysis}

Biochemical data are reported as means \pm s.D. and statistical analysis was performed by ANOVA. Dunnett's post hoc test was applied for comparisons with control and Tukey's post hoc test was performed for multiple comparisons between groups. Unless stated otherwise, the level of statistical significance was arbitrarily set at $0 \cdot 05$. Statistical analysis of immunofluorescence data was performed by applying Mann-Whitney test. All analyses used SPSS (Paris, France) or Instat (GraphPad, San Diego, CA, USA) softwares.

\section{Results}

\section{Leptomycin modulates ER distribution in MCF-7 cells}

The activity of LMB in our experimental conditions was first assessed by examining its effect on the intracellular distribution of $\mathrm{p} 53$, a nuclear protein which is known to constantly shuttle between the nucleus and the cytoplasm. It has been reported previously that LMB induces a nuclear accumulation of p53 in MCF-7 cells (Freedman \& Levine 1998). As illustrated in Fig. 1(upper panel), immunoreactive p53 exhibited a seemingly diffuse distribution in untreated cells (A). Treatment with LMB resulted in a visible concentration

Figure 1 (Upper panel) Effect of LMB on the distribution and expression of p53 and ER in MCF-7 cells. A, C, E: untreated cells; B, D, F: 6$\mathrm{h}$ exposure to $2 \times 10^{-8} \mathrm{M}$ LMB. Immunofluorescence staining was performed with mouse monoclonal anti-p53 antibody (Ab-6; A, B) or rabbit polyclonal anti-ER antibodies (HC-20; C, D; H-184, E, F). Texas Red labeling. Representative result of an experiment which was performed thrice. Magnification bar, $50 \mu \mathrm{m}$. (Lower panel) Frequency histograms illustrating the distribution of nuclear signals (grey levels) in MCF-7 cells treated with LMB $\left(2 \times 10^{-8} \mathrm{M}, 6 \mathrm{~h}\right)$ and processed for ER immunofluorescence staining. Quantitative analysis of nuclear fluorescence was performed as specified in Materials and methods. 

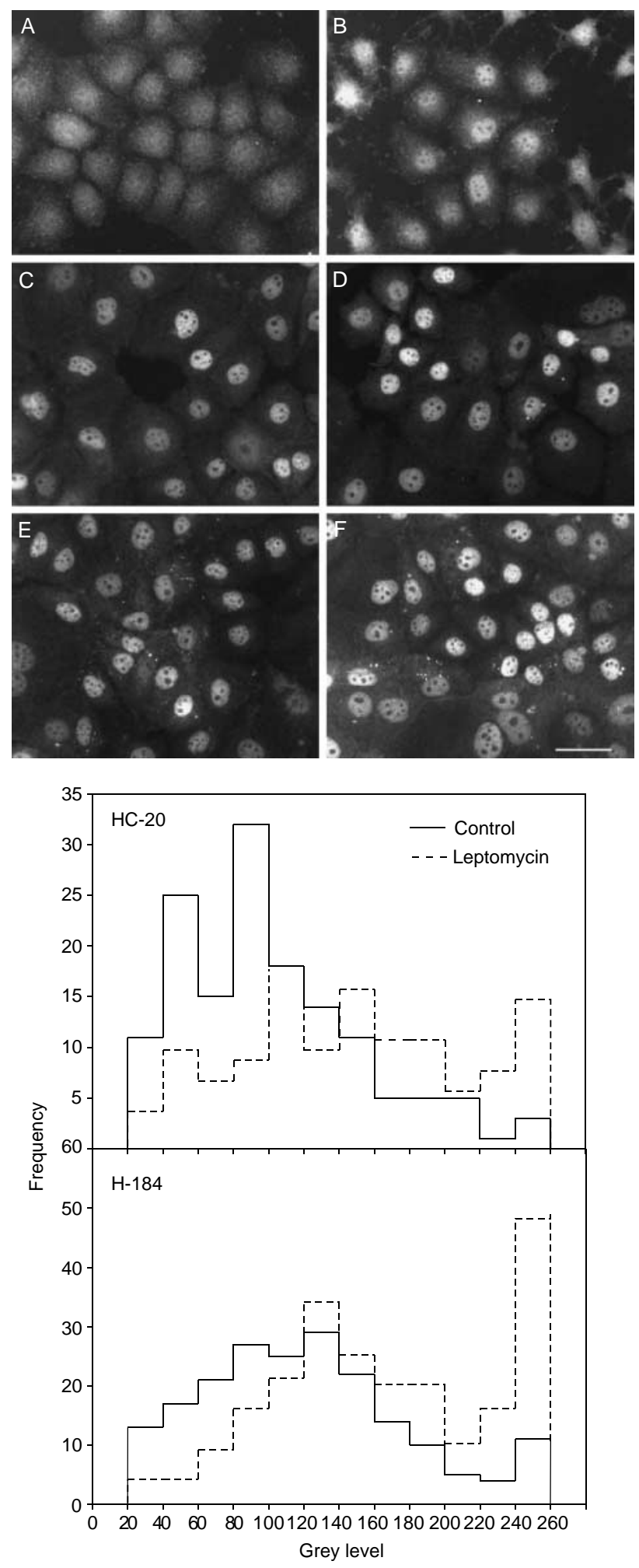
of fluorescence in cell nuclei (B). Quantitative analysis of nuclear signals showed that the augmentation of immunofluorescence intensity reached $40 \%$ in LMBtreated cells, as compared with controls $(P<0 \cdot 001)$.

It is known from previous immunofluorescence studies that in breast carcinoma cells, the bulk of immunoreactive ER appears in nuclei (Laios et al. 2003, 2005, Journé et al. 2004, Nonclercq et al. 2004). The LMB was used to evaluate the possibility that this distribution might actually result from a dynamic equilibrium between nuclear import and export. As revealed by Fig. 1(upper panel), cell exposure to LMB for $6 \mathrm{~h}$ resulted in a clear-cut increase $(29 \%, P<0 \cdot 0001)$ of nuclear immunofluorescence signal (compare $\mathrm{C}$ to $\mathrm{D}$ ) in the cell population. Of note, this result was not related to the application of a particular antibody (namely HC-20 raised against residues 576-595 in the C-terminal region of ER; C and D). Indeed, an antibody raised against a different portion of ER (i.e. H-184 raised against residues 2-184 in the $\mathrm{N}$-terminal region of ER; $\mathrm{E}$ and $\mathrm{F}$ ) also demonstrated an increase of ER nuclear fluorescence in cells treated with LMB ( $17 \%$ increase, $P<0 \cdot 0001$ ). It is noteworthy that the change in ER immunofluorescence pattern following LMB exposure was apparently less marked than that observed for p53 since in untreated cells the latter transcription factor is largely cytoplasmic. Yet, when the nuclear signals associated with ER immunolabeling were plotted as distribution histograms, there was a shift toward higher values in cells treated with LMB (Fig. 1, lower panel).

Quantitative measurement of ER turnover was performed to determine whether the above-described increase of immunoreactive ER in nuclei resulted from an impaired degradation of the receptor. Results, depicted in Fig. 2, show that there is no change in the kinetics of ER elimination in the short term, i.e. during
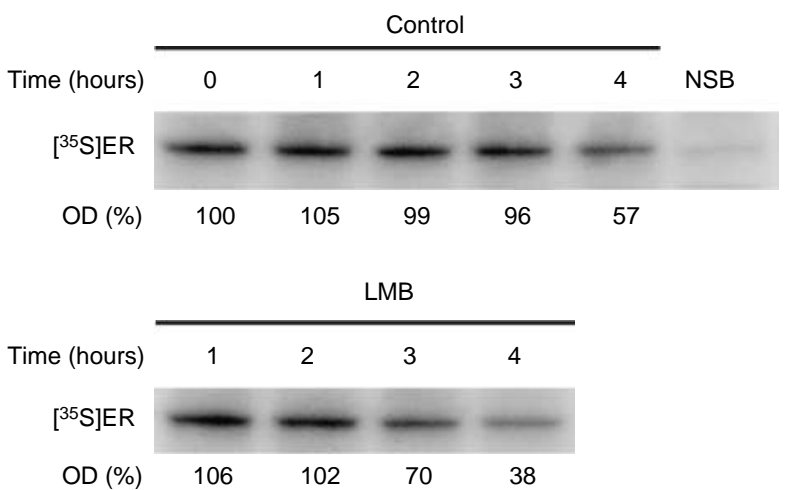

Figure 2 Effect of LMB $\left(2 \times 10^{-8} \mathrm{M}\right)$ on the kinetics of ER degradation. Cells were exposed for $2 \mathrm{~h}$ to $10^{-8} \mathrm{M}\left[{ }^{35} \mathrm{~S}\right]$ methionine in order to achieve protein labeling. As described in Materials and methods, ER radioactivity was assessed at different time intervals during the chase period, in presence or absence of $2 \times 10^{-8} \mathrm{M}$ LMB. NSB, non-specific binding found in the absence of the primary antibody. the first hours of exposure to leptomycin. This is in agreement with a previous study (Calligé et al. 2005) which showed that treatment with LMB for $150 \mathrm{~min}$ failed to affect ER level in MCF-7 cells.

\section{Leptomycin induces ER accumulation in MCF-7 cells}

We next addressed the effect of LMB on cellular ER level under basal conditions (i.e. in absence of ER ligands). Immunoblot analysis presented in Fig. 3A reveals that cell treatment with $\mathrm{LMB}$ alone for $17 \mathrm{~h} \mathrm{led}$ to a sizeable increase in ER content, suggestive of an inhibition of ER elimination after prolonged exposure to this inhibitor. Thus, the LMB-induced augmentation of ER signal seen in immunofluorescence microscopy was followed by ER accumulation.

It has been reported previously (Lee et al. 2002, Nonclercq et al. 2004) that a disruption of Hsp90 activity by heat shock protein inhibitors such as geldanamycin or radicicol causes an ER destabilization which leads to receptor degradation in a ligandindependent manner. This was confirmed by the current immunoblotting analysis showing a marked decline of ER level in cells exposed to radicicol (Fig. 3A). Interestingly, pre-exposure to LMB partly abrogated ER elimination in cells treated with radicicol.

ER agonists and pure estrogen antagonists provoke an increase of ER turnover, leading to receptor downregulation (Dauvois et al. 1993, Devin-Leclercq et al. 1998, El Khissiin \& Leclercq 1999, Journé et al. 2004, Laïos et al. 2005). Immunoblot data depicted in Fig. 3A indicate that $\mathrm{E}_{2}$-induced $\mathrm{ER}$ downregulation was partially reversed by LMB. On the other hand, LMB had no sizeable effect on ER depletion produced by the pure anti-estrogen fulvestrant (ICI 182 870).

As illustrated in Fig. 4, data from western blot analysis were largely confirmed by immunofluorescence microscopy. Thus, examination of Fig. 4C, E, and G shows that the decrease of ER level induced by radicicol (ligand-independent), as well as receptor downregulation associated with $\mathrm{E}_{2}$ or fulvestrant binding, is reflected by a marked loss of nuclear immunofluorescence signal as compared with control (4A). However, a partial restoration of signal intensity can be seen in cells pretreated with LMB prior to radicicol (4D) or $\mathrm{E}_{2}(4 \mathrm{~F})$. Obviously, this is not the case for cells treated with fulvestrant $(4 \mathrm{H})$. It must also be noted that exposure to LMB alone produces a definite enhancement of signal in cell nuclei $(4 \mathrm{~B})$.

Proteasome inhibition (e.g. MG-132) and a number of triphenylethylene-based anti-estrogens (e.g. OH-Tam) decrease ER breakdown, thereby causing ER accumulation (Wijayaratne \& McDonnell 2001, Laïos et al. 2003, 2005, Marsaud et al. 2003). Benzothiophen anti-estrogens (e.g. LY 117 018) similarly interfere with ER proteolysis and suppress ligand-induced 

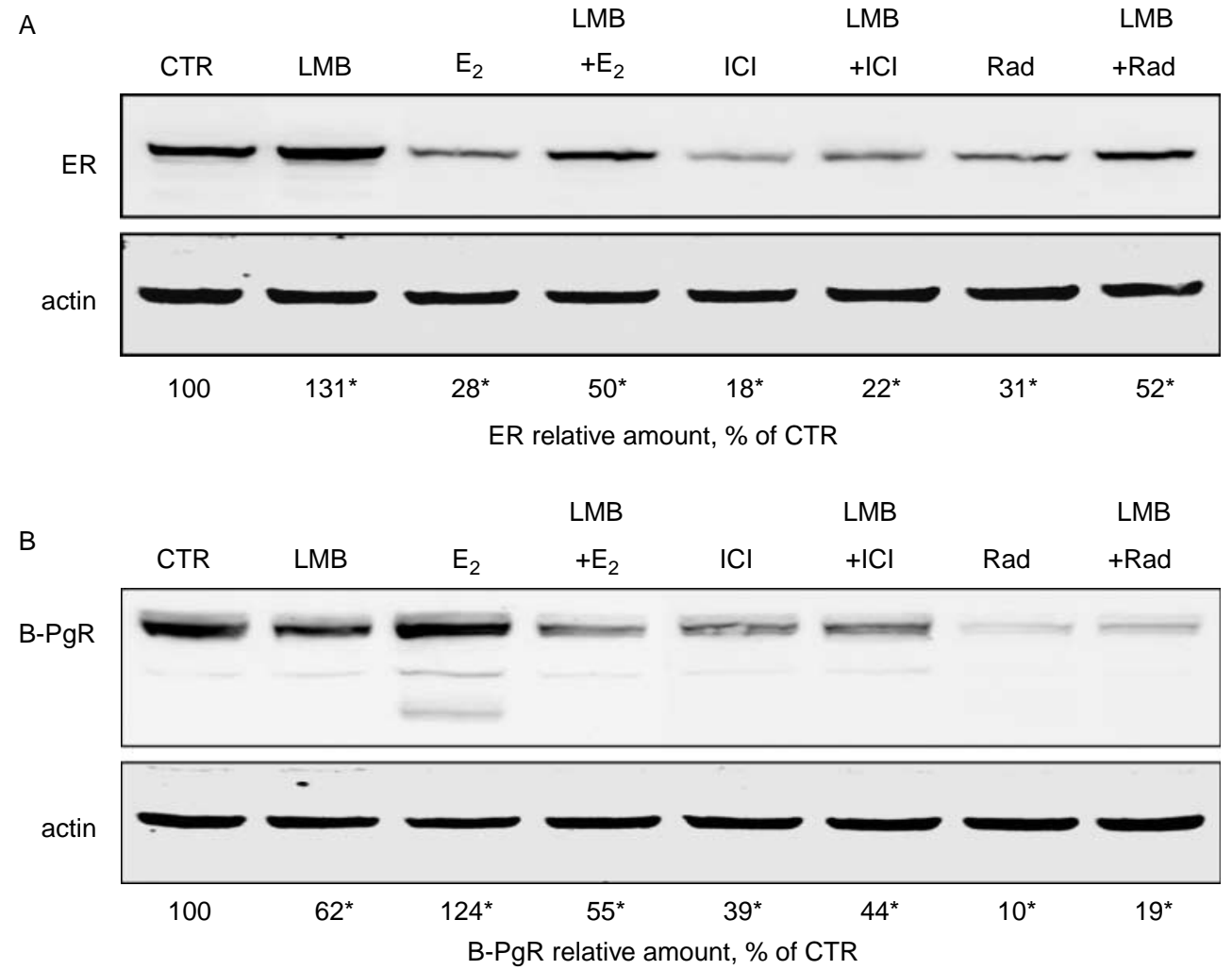

Figure $3(A)$ Effect of LMB $\left(2 \times 10^{-8} M\right)$, followed by $E_{2}\left(10^{-9} M\right)$, fulvestrant $\left(10^{-7} M\right)$, or radicicol $\left(2 \times 10^{-6} \mathrm{M}\right)$ on steady-state level of ER in MCF-7 cells, as assessed by SDS-PAGE and immunoblotting with mouse monoclonal anti-ER antibody $(\mathrm{F}-10)$. Immunoblot analysis was performed on cell lysates $\left(25 \mu \mathrm{g}\right.$ proteins/lane) after successive treatments with LMB $(17 \mathrm{~h})$ and $\mathrm{E}_{2}$, fulvestrant $(\mathrm{ICI})$, or radicicol (Rad; $6 \mathrm{~h}$ ). The amount of immunoreactive ER was quantified as described in Materials and methods and expressed as a percentage of control (CTR, untreated cells). Values are means of four determinations (S.D. were omitted for the clarity of presentation). Asterisks denote values significantly different from control $\left(P<0.01\right.$, Dunnett's post test). (B) Effect of LMB $\left(2 \times 10^{-8} \mathrm{M}\right)$, followed by $\mathrm{E}_{2}\left(10^{-9} \mathrm{M}\right)$, fulvestrant $\left(10^{-7} \mathrm{M}\right)$, or radicicol $\left(2 \times 10^{-6} \mathrm{M}\right)$ on PgR expression in MCF-7 cells, as assessed by SDS-PAGE and immunoblotting with mouse monoclonal anti-PgR antibodies (NCL-PGR-AB). Immunoblot analysis was performed on cell lysate samples equivalent to $50 \mu \mathrm{g}$ proteins. As already noted (Journé et al. 2004), the major band of immunoreactive material corresponds to the $120 \mathrm{kDa} \mathrm{PgR}-\mathrm{B}$ isoform. Results are expressed as a percentage of control (CTR, untreated cells). Values are means of six determinations. Asterisks denote values significantly different from control $(P<0 \cdot 01$, Dunnett's post test). Actin was used as a loading control.

receptor downregulation. The action of LMB in combination with these compounds on ER level was assessed by immunoblotting (Fig. 5). Examination of data reveals that LMB slightly enhanced the inhibitory effects of anti-estrogens on proteasome-mediated ER degradation. On the other hand, MG-132 did not augment LMB-induced ER accumulation.

\section{Leptomycin interferes with ER-mediated gene transactivation}

In order to determine whether LMB has an impact on ER function, we evaluated the transactivation capacity of ER in MCF-7 exposed to LMB alone, or in combination with $\mathrm{E}_{2}$, fulvestrant, or radicicol. Immunoblot data presented in Fig. 3B illustrate the effect of various treatments on the expression of PgR gene, known to be targeted by ER. Cell treatment with LMB alone produced a marked decrease ( $\sim 40 \%$ ) of PgR expression. Exposure to LMB completely suppressed $\mathrm{E}_{2}$-induced enhancement of $P g R$ gene transactivation and did not modify fulvestrant-induced inhibition of PgR expression. Of note, radicicol by itself caused a marked decrease of $\mathrm{PgR}$ level. This confirmed previous work (Lange et al. 2000, Chadli et al. 2006) showing that Hsp90 interacts with this receptor and contributes to its stability.

The analysis of LMB effect on ER-mediated gene transactivation was extended by assessing the activity of an ERE-driven luciferase reporter gene in stably transfected MCF-7 cells (MVLN). As shown in Fig. 6A, results were 

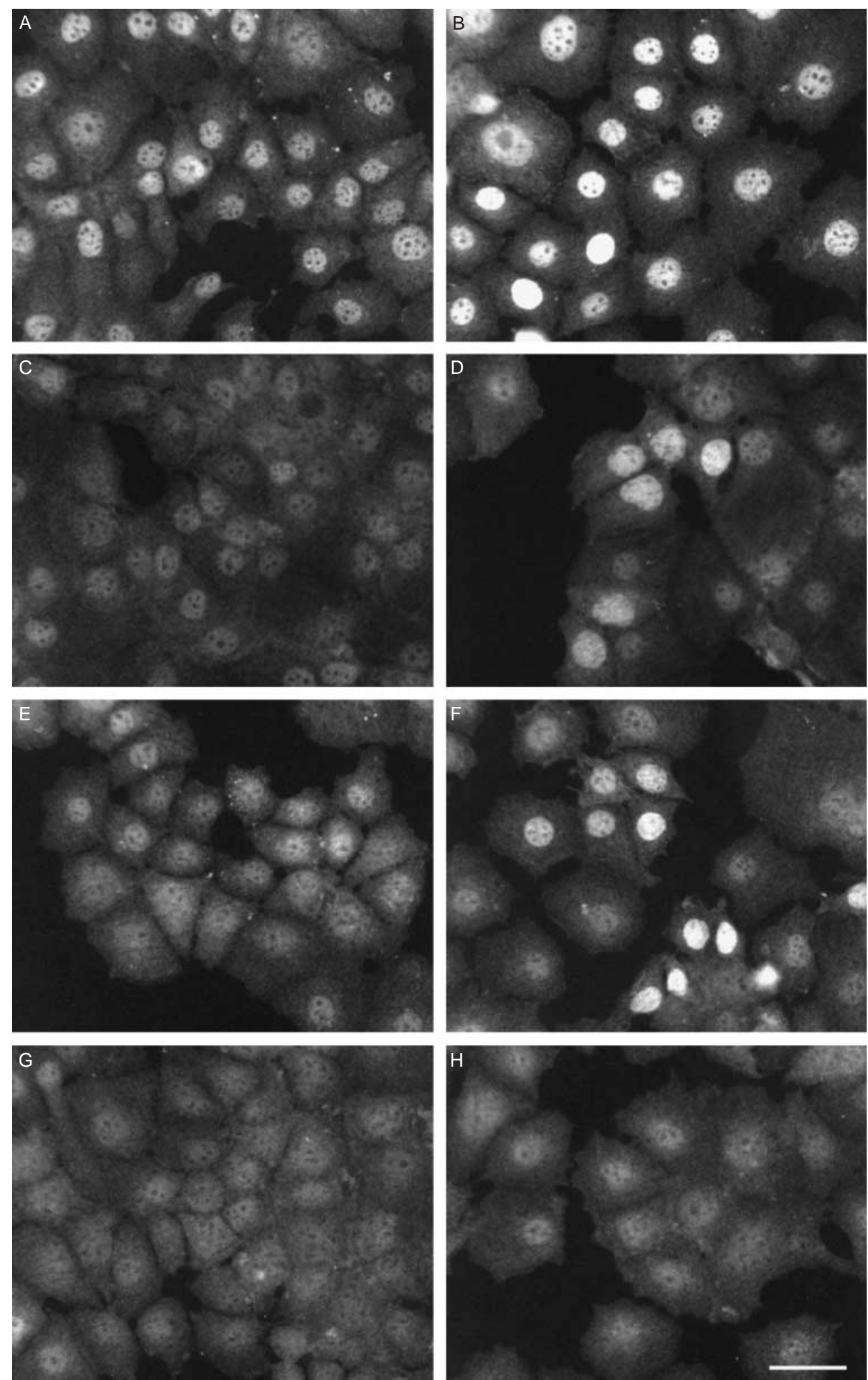


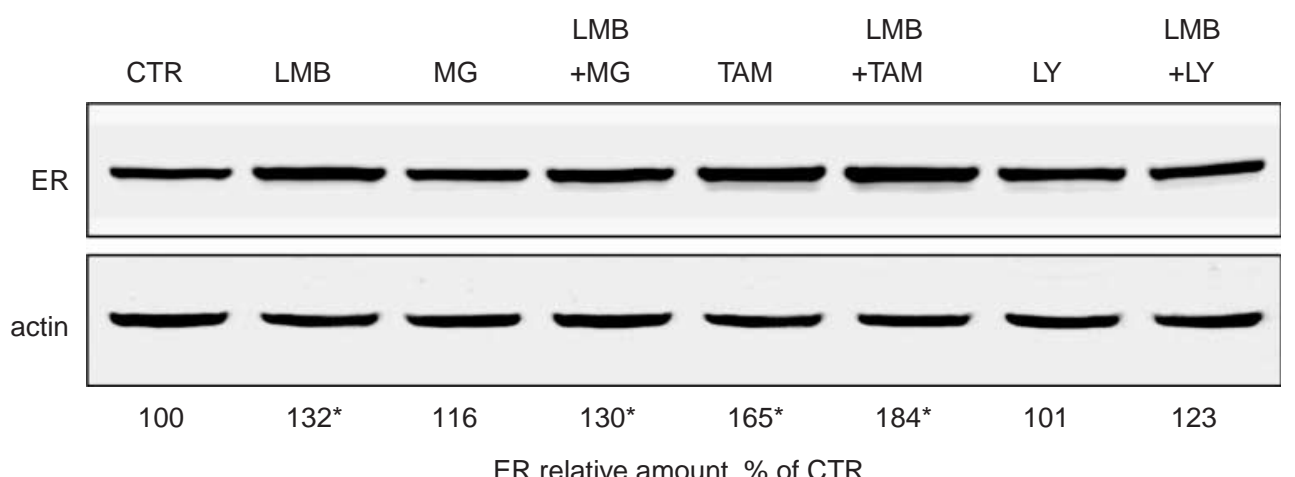

Figure 5 Effect of LMB $\left(2 \times 10^{-8} \mathrm{M}\right), \mathrm{MG}-132\left(\mathrm{MG}, 10^{-5} \mathrm{M}\right), \mathrm{OH}-\mathrm{Tam}\left(\mathrm{TAM}, 10^{-7} \mathrm{M}\right), \mathrm{LY} 117018$ (LY, $10^{-7} \mathrm{M}$ ), or combinations thereof on steady-state level of ER in MCF-7 cells, as assessed by SDS-PAGE and immunoblotting with mouse monoclonal anti-ER antibody ( $\mathrm{F}-10)$, as specified in Fig. $3 \mathrm{~A}$. Cells were exposed to LMB for $24 \mathrm{~h}$, with or without MG-132 (last $6 \mathrm{~h}$ of treatment), $\mathrm{OH}-\mathrm{Tam}$ (last $22 \mathrm{~h}$ of treatment), or LY 117018 (last $22 \mathrm{~h}$ of treatment). Results are expressed as percentage of control (CTR, untreated cells). Results are expressed as a percentage of control (CTR, untreated cells). Values are means of four determinations. Asterisks denote values significantly different from control $(P<0 \cdot 01$, Dunnett's post test). Actin was used as a loading control.

quite similar to those obtained from the analysis of $\mathrm{PgR}$ gene expression. Thus, an $\sim 40 \%$ reduction of luciferase activity was observed in cells exposed to LMB alone. The latter inhibitor fully abrogated $\mathrm{E}_{2}$-induced stimulation and failed to modify the inhibitory effect of radicicol, despite the fact that it partly suppressed agonist-induced ER downregulation (in the case of $\mathrm{E}_{2}$ ) and ligandindependent receptor degradation (in the case of radicicol; Fig. 3A). Figure 7 illustrates dose-response experiments where ER-mediated transactivation was measured as a function of $\mathrm{E}_{2}$ and fulvestrant concentrations, in the absence or the presence of LMB. Examination of the data reveals that LMB provoked a $60 \%$ decrease in the maximal effect of $\mathrm{E}_{2}$ (upper panel), suggesting that a substantial proportion of ER had become nonfunctional. Furthermore, LMB slightly enhanced fulvestrant-induced inhibition of ER-mediated transactivation (lower panel). This could be expected since it does not prevent ER downregulation produced by this pure anti-estrogen (Fig. 3A). Thus, LMB depressed the transactivation capacity of ER regardless of the binding status of the receptor.

It has been reported previously (Lonard et al. 2000) that a blockade of ER turnover resulting from proteasome inhibition causes a loss of transactivation capacity. This was confirmed in this study by measuring $\mathrm{E}_{2}$-induced reporter gene expression in the absence or the presence of the proteasome inhibitor MG-132 (Fig. 6B). It is noteworthy that in these conditions, the loss of transactivation capacity occurs despite an increase in ER level (Laïos et al. 2005). Interestingly, LMB induced a further decrease of ER transactivation capacity in cells exposed to MG-132 or MG-132 plus $\mathrm{E}_{2}$ (Fig. 6B). Similarly, MG-132 enhanced the decrease of ER transactivation capacity in cells treated with the $\mathrm{E}_{2}$ plus LMB combination (Fig. 6B). It can be inferred from these data that LMB and MG-132 interfere with distinct steps of the mechanism underlying ER stability and ER-mediated gene transactivation.

\section{Discussion}

Unlike GR, which in its free state resides in the cytoplasm, ER localization appears predominantly nuclear, regardless of the binding status of the receptor. This has been attributed to the fact that ER exhibits a constitutive (i.e. ligand-independent) nuclear localization signal (NLS) recognized by importins which mediate nuclear entry, whereas in the case of GR the NLS is ligand-modulated (Picard et al. 1990). There are, however, reasons to think that the nuclear localization of ER is more likely the net result of a dynamic shuttling rather than of a sequestration within the nuclear compartment. For instance, recent work shows that estrogen-induced phosphorylation of SRC3/AIB1, a co-activator of ER, requires direct interaction with the receptor and probably occurs in the cytoplasm (Zheng et al. 2005).

As revealed by this study, exposure to LMB alone induces ER accumulation in nuclei of MCF-7 cells, suggesting that in basal conditions a fraction of the

Figure 4 Effect of LMB $\left(2 \times 10^{-8} \mathrm{M} ; 17-\mathrm{h}\right.$ exposure) followed by radicicol $\left(2 \times 10^{-6} \mathrm{M}\right), \mathrm{E}_{2}\left(10^{-9} \mathrm{M}\right)$, or fulvestrant $\left(10^{-7} \mathrm{M}\right.$; $6-\mathrm{h}$ exposures) on ER expression in MCF-7 cells, as documented by immunofluorescence staining with rabbit polyclonal anti-ER antibody (HC-20). (A) untreated cells; (B) LMB; (C) radicicol; (D) LMB followed by radicicol; (E) $E_{2}$; $(F)$ LMB followed by $E_{2}$; (G) fulvestrant; (H) LMB followed by fulvestrant. Texas Red labeling. Representative result of an experiment which was performed thrice. Magnification bar, $50 \mu \mathrm{m}$. 

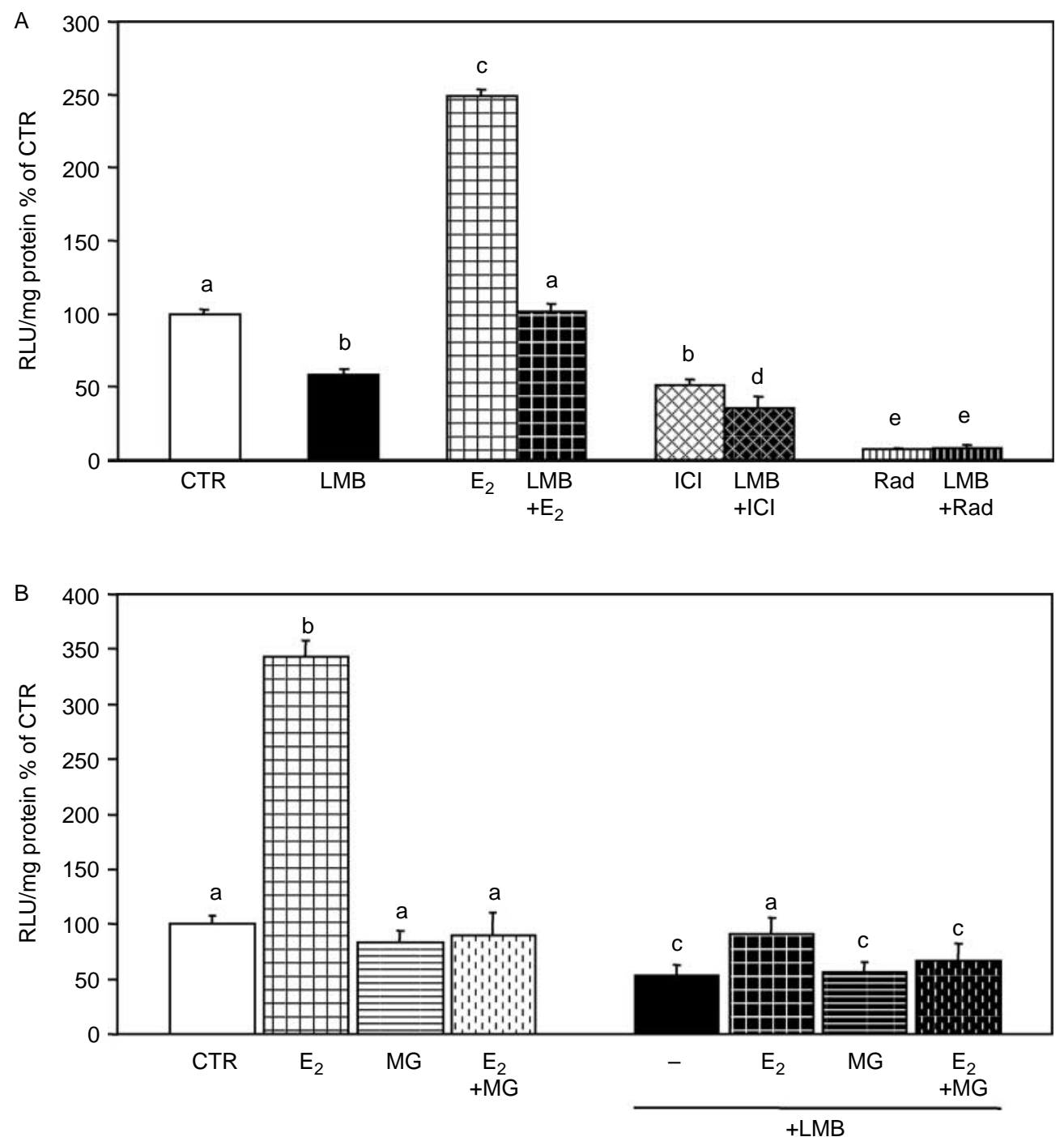

Figure $6(A)$ Effect of $L M B\left(2 \times 10^{-8} M\right), E_{2}\left(10^{-9} M\right)$, fulvestrant $\left(I C l, 10^{-7} M\right)$, radicicol (Rad, $\left.2 \times 10^{-6} M\right)$, or combinations thereof on ERE-driven gene transcription in MVLN cells. Cells were exposed to LMB for $24 \mathrm{~h}$, with or without $\mathrm{E}_{2}$, fulvestrant, or radicicol (last $18 \mathrm{~h}$ of treatment). Luciferase reporter gene expression was assayed as specified in Materials and methods. Data are expressed as a percentage of control (CTR, untreated cells). Each column represents the mean of six determinations ( \pm s.D.). (B) Effect of LMB $\left(2 \times 10^{-8} \mathrm{M}\right), \mathrm{E}_{2}\left(10^{-9} \mathrm{M}\right), \mathrm{MG}-132\left(10^{-6} \mathrm{M}\right)$, or combinations thereof on ERE-driven gene transcription in MVLN cells. Cells were exposed to LMB for $22 \mathrm{~h}$, with or without $\mathrm{E}_{2}$ and/or MG-132 (last $6 \mathrm{~h}$ of treatment). Luciferase reporter gene expression was assayed as specified in Materials and methods. Data are expressed as percentage of control (CTR, untreated cells). Each column represents the mean of six determinations ( \pm S.D.). Different letters point to significant differences $(P<0.05$, Tukey's post hoc test) between values. Pooled results from two experiments.

receptor population undergoes nuclear export mediated by Crm1. This finding is consistent with the abovementioned work of Itoh et al. (2002) on GR and the recent demonstration by Lee \& Bai (2002) that in Ishikawa cells ER exit from the nucleus is abrogated by LMB. In a similar way, nuclear export of $\mathrm{PgR}$ has been reported to be hindered by LMB (Qiu et al. 2003). By contrast, for androgen receptor (Saporita et al. 2003), nuclear export has been claimed to be insensitive to LMB. Of note, it has been pointed out that conclusions regarding the mechanism of nucleocytoplasmic trafficking of steroid receptors - in particular the role of $\mathrm{Crm} 1$ and calreticulin - can be biased by the methodological approach (Walther et al. 2003).

As pointed out by Shank \& Paschal (2005), steroid receptors do not exhibit the leucine-rich, hydrophobic NES typically found in proteins which interact with Crm1 for nuclear export. Thus, the molecular mechanism by 


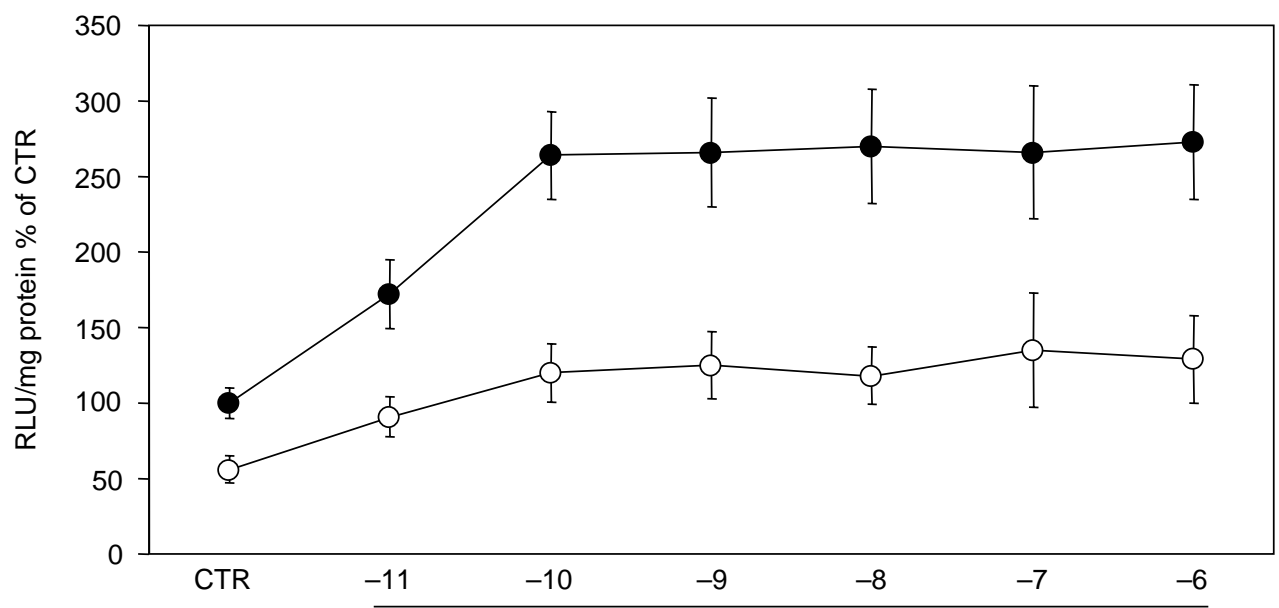

$E_{2}$ concentration, $\log M$

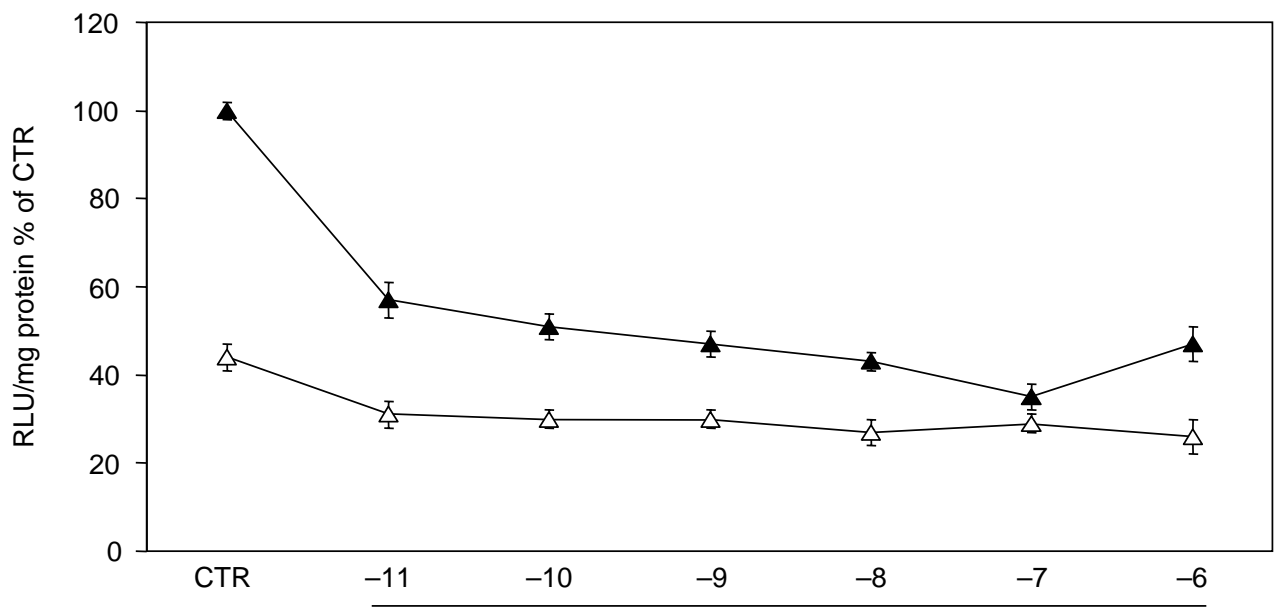

Fulvestrant concentration, $\log \mathrm{M}$

Figure 7 Effect of $E_{2}$ (upper panel) and fulvestrant (lower panel), in presence (open symbols) or absence (filled symbols) of LMB $\left(2 \times 10^{-8} \mathrm{M}\right)$, on ERE-driven reporter gene transcription in MVLN cells. Cells were exposed to LMB for $24 \mathrm{~h}$, in combination with $\mathrm{E}_{2}$ (circles) or fulvestrant (triangles) at increasing concentrations (last $18 \mathrm{~h}$ of treatment). Luciferase gene expression was assayed as specified in Materials and methods. Data are expressed as a percentage of control (CTR, untreated cells). Each symbol is the mean of six determinations ( \pm s.D.). All values obtained in the presence of $L M B$ are significantly lower than values obtained in the absence of this drug $(P<0 \cdot 05$, Tukey's post hoc test). Pooled results from two experiments.

which LMB produces an increase of ER in cell nuclei remains a matter of debate. As a matter of fact, this is also true for the effect of LMB on the sub-cellular trafficking of GR and PgR (see above). It could be that steroid receptors interact with $\mathrm{Crm} 1$ thanks to a co-regulator behaving as an adapter. In this context, it has been recently reported that steroid receptor co-activator-1 (a member of the p160 family) is exported from cell nuclei by a LMB-sensitive process (Amazit et al. 2003).

LMB-induced accumulation of ER in nuclei was seen as well in basal conditions (LMB alone) as in cells exposed to radicicol, an inhibitor which disrupts
Hsp90-mediated chaperoning and increases the rate of ER degradation. It is noteworthy that the mechanism of ER elimination in radicicol-treated cells somehow differs from that operating in basal conditions since in the former case ER breakdown is not blocked by proteasome inhibition (Nonclercq et al. 2004). Yet, in both cases LMB treatment interferes with ER degradation, resulting in an increase of ER level relative to corresponding controls. This strongly suggests that unliganded ER is degraded outside the nuclear compartment, whether it is associated or not with Hsp90. The importance of nucleocytoplasmic 
translocation in the process of ER degradation is illustrated further by the fact that the proteasome inhibitor MG-132 had no sizeable effect on the increase of ER level produced by prolonged exposure to LMB. LMB alone, by keeping ER away from cytoplasmic proteasomes, achieved a maximal effect on nuclear accumulation.

Partial anti-estrogens perturb ER turnover by inhibiting the breakdown of the receptor (Laios et al. 2003). This has been attributed to the fact that once bound to ER, they do not allow the recruitment of co-regulators required for receptor degradation. As a consequence, these antagonists cause ER accumulation (in the case of tamoxifen and parent compounds) and suppress ligand-induced ER downregulation (in the case of raloxifene and related derivatives). As shown in this study, LMB given in combination with OH-Tam or LY 117018 produced an additive effect on ER level. It can be inferred from these observations that the impact of partial anti-estrogens on ER turnover is not related to an impairment of nucleoplasmic translocation.

Estrogen agonists (e.g. $\mathrm{E}_{2}$ ) and steroidal antiestrogens (e.g. fulvestrant, RU 58668) accelerate ER turnover, provoking a decrease of ER level (downregulation). Even though in both cases the breakdown of liganded ER involves the ubiquitin-proteasome system (sensitivity to proteasome inhibitors), it has been shown that the mechanism underlying ER degradation differs with respect to the type of ligand. Thus, $\mathrm{E}_{2}$-induced downregulation is partially abrogated by cycloheximide, whereas fulvestrant- or RU 58668 induced downregulation appears insensitive to cycloheximide (El Khissiin et al. 1999, Laïos et al. 2005). Likewise, in the current study we observed that LMB partially abrogates ER downregulation caused by $\mathrm{E}_{2}$ while it fails to modify the effect of fulvestrant on ER level. These findings are in accordance with observations reported recently by Calligé $e t$ al. $(2005,2006)$ and indicate that estrogen-liganded ER must translocate to the cytoplasm in order to be processed by extranuclear proteasomes, whereas fulvestrant-bound ER is destroyed in nuclear proteasomes. It is indeed known that proteasomes distribute in the nucleus as well as in the cytoplasm (Wójcik \& DeMartino 2003). Furthermore, recent work provides strong evidence that the degradation of fulvestrant-bound ER indeed occurs in nuclear matrix-associated proteasomes (Long \& Nephew 2006).

As an alternative hypothesis, it is conceivable that posttranslational modification of ER or (an) ER co-activator(s) must occur in the cytoplasm prior to receptor degradation. For instance, it has been shown that the breakdown of unliganded ER requires ubiquitination by ubiquitin ligase CHIP, which mostly resides in the cytoplasm (Tateishi et al. 2004). However, this does not explain why LMB abrogates $\mathrm{E}_{2}$-induced ER downregulation, since the degradation of liganded receptor is CHIPindependent (Tateishi et al. 2004). On the other hand, the co-activator SRC3/AIB1, which is thought to be involved in the control of ER proteasomal degradation (Shao et al. 2004), undergoes estrogen-induced phosphorylation when associated with extranuclear ER (Zheng et al. 2005). This latter hypothesis would account for the insensitivity of fulvestrant-induced ER degradation to LMB since the binding of this pure anti-estrogen does not result in the recruitment of co-activators of the SRC family (Jaber et al. 2006).

From the analysis of endogenous (MCF-7 cells) and reporter (MVLN cells) gene expression, it is clear that LMB-induced accumulation of ER in the nuclear compartment results in a decrease rather than in an increase of transactivation activity. This seems to contrast with previous work showing that the inhibition of proteasome-mediated ER breakdown (either by disruption of ubiquitination or by blockade of proteasome activity) and the consecutive rise of receptor level tend to augment the expression of ER-responsive genes (Fan et al. 2004). Yet, recent investigations of our group reveal that ER accumulation resulting from proteasome inhibition is not accompanied by a concomitant increase of ER-mediated gene transactivation (Laïos et al. 2005). Thus, under some circumstances ER transactivation capacity does not necessarily reflect ER protein level. It seems that, regardless of the underlying mechanism (proteasome inhibition or disruption of nucleocytoplasmic translocation), ER rescued from proteasomal degradation partly occurs in an inactive form. This suggests that after its production and chaperone-mediated maturation, ER spontaneously evolves toward a state of non-functionality (Laïos $e t \mathrm{al}$. 2005). Anyway, an inhibitory effect of LMB on receptormediated transactivation has also been reported for $\mathrm{PgR}$, suggesting that nucleocytoplasmic shuttling is critical for efficient transactivation activity of nuclear receptors (Qiu et al. 2003).

To conclude, findings reported in the current study point to an involvement of exportin Crm1 in nuclear export of ER. Furthermore, they highlight the importance of nucleocytoplasmic shuttle in ER level and ER transactivation function.

\section{Acknowledgements}

This study received financial support from the Belgian Fund for Medical Scientific Research (Grant no. 3.4512.03), from the Fondation Medic and from the Fondation Lambeau-Marteaux. G Laurent is Senior Research Associate of the National Fund for Scientific Research (Belgium). 


\section{Funding}

The authors declare no conflict of interest that would have prejudiced the impartiality of the current study.

\section{References}

Alarid ET 2006 Lives and times of nuclear receptors. Molecular Endocrinology 20 1972-1981.

Alarid ET, Bakopoulos N \& Solodin N 1999 Proteasome-mediated proteolysis of estrogen receptor: a novel component in autologous down-regulation. Molecular Endocrinology 13 1522-1534.

Amazit L, Alj Y, Tyagi RK, Chaucherau A, Loosfelt H, Pichon C, Pantel J, Foulon-Guinchard E, Leclerc P, Milgrom E et al. 2003 Subcellular localization and mechanisms of nucleocytoplasmic trafficking of steroid receptor coactivator-1. Journal of Biological Chemistry 278 32195-32203.

Aranda A \& Pascual A 2001 Nuclear hormone receptors and gene expression. Physiological Reviews 81 1269-1304.

Bardin A, Boulle N, Lazennec G, Vignon F \& Pujol P 2004 Loss of ER $\beta$ expression as a common step in estrogen-dependent tumor progression. Endocrine-Related Cancer 11 537-551.

Bjornstrom L \& Sjoberg M 2005 Mechanisms of estrogen receptor signaling: convergence of genomic and nongenomic actions on target genes. Molecular Endocrinology 19 833-842.

Brohée R, Nonclercq D, Journé F, Toubeau G, Falmagne P, Leclercq G, Heuson-Stiennon J-A \& Laurent G 2000 Demonstration of estrogen receptors and of estrogen responsiveness in the HKT-1097 cell line derived from diethylstilbestrol-induced kidney tumors. In Vitro Cellular and Developmental Biology. Animal 36 640-649.

Calligé M \& Richard-Foy H 2006 Ligand-induced estrogen receptor $\alpha$ degradation by the proteasome: new actors? Nuclear Receptor Signaling 4 e004.

Calligé M, Kieffer I \& Richard-Foy H 2005 CSN5/Jab1 is involved in ligand-dependent degradation of estrogen receptor $\alpha$ by the proteasome. Molecular and Cellular Biology 25 4349-4358.

Chadli A, Graham JD, Abel MG, Jackson TA, Gordon DF, Wood WM, Felts SJ, Horwitz KB \& Toft D 2006 GCUNC-45 is a novel regulator for the progesterone receptor/hsp90 chaperoning pathway. Molecular and Cellular Biology 26 1722-1730.

Ciocca DR \& Fanelli MA 1997 Estrogen receptors and cell proliferation in breast cancer. Trends in Endocrinology and Metabolism 8 313-321.

Clarke RB, Anderson E \& Howell A 2004 Steroid receptors in human breast cancer. Trends in Endocrinology and Metabolism 15 316-323.

Dauvois S, White R \& Parker MG 1993 The antiestrogen ICI 182780 disrupts estrogen receptor nucleocytoplasmic shuttling. Journal of Cell Science 106 1377-1388.

Demirpence E, Duchesne MJ, Badia E, Gagne D \& Pons M 1993 MVLN cells: a bioluminescent MCF-7-derived cell line to study the modulation of estrogenic activity. Journal of Steroid Biochemistry and Molecular Biology 46 355-364.

Dennis AP \& O'Malley BW 2005 Rush hour at the promoter: how the ubiquitin-proteasome pathway polices the traffic flow of nuclear receptor-dependent transcription. Journal of Steroid Biochemistry and Molecular Biology 93 39-51.

Devin-Leclerc J, Meng X, Delahave F, Leclerc P, Baulieu E-E \& Catelli M-G 1998 Interaction and dissociation by ligands of estrogen receptor and Hsp90: the antiestrogen RU 58668 induces a protein synthesis-dependent clustering of the receptor in the cytoplasm. Molecular Endocrinology 12 842-854.

Early Breast Cancer Trialists Collaborative Group 1998 Tamoxifen for early breast cancer: an overview of the randomized trials. Lancet 351 1451-1467.

Evinger AJ \& Levin ER 2005 Requirements for estrogen receptor $\alpha$ membrane localization and function. Steroids 70 361-363.
Fan M, Nakshatri H \& Nephew KP 2004 Inhibiting proteasomal proteolysis sustains estrogen receptor- $\alpha$ activation. Molecular Endocrinology 18 2603-2615.

Freedman DA \& Levine AJ 1998 Nuclear export is required for degradation of endogenous p53 by MDM2 and human papillomavirus E6. Molecular and Cellular Biology 18 7288-7293.

Gruber CJ, Gruber DM, Gruber IM, Wieser F \& Huber JC 2004 Anatomy of the estrogen response element. Trends in Endocrinology and Metabolism 15 73-78.

Gustafsson JA \& Warner M 2000 Estrogen receptor beta in the breast: role in estrogen responsiveness and development of breast cancer. Journal of Steroid Biochemistry and Molecular Biology 74 245-248.

Htun H, Holth LT, Walker D, Davie JR \& Hager GL 1999 Direct visualization of the human estrogen receptor alpha reveals a role for ligand in the nuclear distribution of the receptor. Molecular Biology of the Cell 10 471-486.

Itoh M, Adachi M, Yasui H, Takekawa M, Tanaka H \& Imai K 2002 Nuclear export of glucocorticoid receptor is enhanced by c-Jun N-terminal Kinase-mediated phosphorylation. Molecular Endocrinology 16 2382-2392.

Jaber BM, Gao T, Huang L, Karmakar S \& Smith CL 2006 The pure estrogen receptor antagonist ICI 182780 promotes a novel interaction of estrogen receptor- $\alpha$ with the $3^{\prime}, 5^{\prime}$-cyclic adenosine monophosphate response element-binding protein/p300 coactivators. Molecular Endocrinology 20 2695-2710.

Jacquot Y, Laïos I, Cleeren A, Nonclercq D, Bermont L, Refouvelet B, Boubekeur K, Xicluna A, Leclercq G \& Laurent G 2007 Synthesis, structure, and estrogenic activity of 4-amino-3-(2-methylbenzyl) coumarins on human breast carcinoma cells. Bioorganic and Medicinal Chemistry 15 2269-2282.

Journé F, Body J-J, Leclercq G, Nonclercq D \& Laurent G 2004 Estrogen responsiveness of IBEP-2, a new human cell line derived from breast carcinoma. Breast Cancer Research and Treatment $\mathbf{8 6}$ $39-53$.

Kau TR \& Silver PA 2003 Nuclear transport as a target for cell growth. Drug Discovery Today 8 78-85.

Kawata M, Matsuda K, Nishi M, Ogawa H \& Ochiai I 2001 Intracellular dynamics of steroid hormone receptor. Neuroscience Research $\mathbf{4 0}$ 197-203.

Kelly MJ \& Levin ER 2001 Rapid actions of plasma membrane estrogen receptors. Trends in Endocrinology and Metabolism 12 152-156.

El Khissiin A \& Leclercq G 1999 Implication of proteasome in estrogen receptor degradation. FEBS Letters 448 160-166.

Laïos I, Journé F, Laurent G, Nonclercq D, Toillon R-A, Seo H-S \& Leclercq G 2003 Mechanisms governing the accumulation of estrogen receptor alpha in MCF-7 breast cancer cells treated with hydroxytamoxifen and related antiestrogens. Journal of Steroid Biochemistry and Molecular Biology 87 207-221.

Laïos I, Journé F, Nonclercq D, Vidal DS, Toillon R-A, Laurent G \& Leclercq G 2005 Role of the proteasome in the regulation of estrogen receptor $\alpha$ turnover and function in MCF-7 breast carcinoma cells. Journal of Steroid Biochemistry and Molecular Biology 94 347-359.

Lange CA, Shen T \& Horwitz KB 2000 Phosphorylation of human progesterone receptors at serine-294 by mitogen-activated protein kinase signals their degradation by the $26 \mathrm{~S}$ proteasome. PNAS $\mathbf{9 7}$ 1032-1037.

Leclercq G, Lacroix M, Laïos I \& Laurent G 2006 Estrogen receptor alpha: impact of ligands on intracellular shuttling and turnover rate in breast cancer cells. Current Cancer Drug Targets 6 39-64.

Lee H \& Bai W 2002 Regulation of estrogen receptor nuclear export by ligand-induced and p38-mediated receptor phosphorylation. Molecular and Cellular Biology 22 5835-5845.

Lee M-O, Kim E-O, Kwon HJ, Kim YM, Kang H-J, Kang H \& Lee J-E 2002 Radicicol represses the transcriptional function of the estrogen receptor by suppressing the stabilization of the receptor by heat shock protein 90. Molecular and Cellular Endocrinology 188 $47-54$. 
Levin ER 2001 Cell localization, physiology and nongenomic actions of estrogen receptors. Journal of Applied Physiology 91 1860-1867.

Liu J \& DeFranco DB 2000 Protracted nuclear export of glucocorticoid receptor limits its turnover and does not require the exportin 1/Crm1-directed nuclear export pathway. Molecular Endocrinology 14 $40-51$.

Lonard DM, Nawaz Z, Smith CL \& O'Malley BW 2000 The 26S proteasome is required for estrogen receptor- $\alpha$ and coactivator turnover and for efficient estrogen receptor- $\alpha$ transactivation. Molecular Cell 5 939-948.

Long X \& Nephew KP 2006 Fulvestrant (ICI182, 780)-dependent interacting proteins mediate immobilization and degradation of estrogen receptor- $\alpha$. Journal of Biological Chemistry 281 9607-9615.

Lösel RM, Falkenstein E, Feuring M, Schultz A, Tillmann H-C, RossolHaseroth K \& Wehling M 2003 Nongenomic steroid action: controversies, questions, and answers. Physiological Reviews $\mathbf{8 3}$ 965-1016.

Marsaud V, Gougelet A, Maillard S \& Renoir JM 2003 Various phosphorylation pathways, depending on agonist and antagonist binding to endogenous estrogen receptor $\alpha(\mathrm{ER} \alpha)$, differentially affect ER $\alpha$ extractability, proteasome-mediated stability, and transcriptional activity in human breast cancer cells. Molecular Endocrinology 17 2013-2027.

Maruvada P, Baumann CT, Hager GL \& Yen PM 2003 Dynamic shuttling and intranuclear mobility of nuclear hormone receptors. Journal of Biological Chemistry 278 12425-12432.

Nawaz Z \& O'Malley BW 2003 Urban renewal in the nucleus: is protein turnover by proteasomes absolutely required for nuclear receptorregulated transcription? Molecular Endocrinology 18 493-499.

Nonclercq D, Journé F, Body J-J, Leclercq G \& Laurent G 2004 Ligandindependent and agonist-mediated degradation of estrogen receptor- $\alpha$ in breast carcinoma cells: evidence for distinct degradative pathways. Molecular and Cellular Endocrinology 227 53-65.

O'Lone R, Frith MC, Karlsson EK \& Hansen U 2004 Genomic targets of nuclear estrogen receptors. Molecular Endocrinology 18 1859-1875.

Pemberton LF \& Paschal BM 2005 Mechanisms of receptor-mediated nuclear import and nuclear export. Traffic 6 187-198.

Picard D, Kumar V, Chambon P \& Yamamoto KR 1990 Signal transduction by steroid hormones: nuclear localization is differentially regulated in estrogen and glucocorticoid receptors. Cell Regulation 1 291-299.

Platet N, Cathiard AM, Gleizes M \& Garcia M 2004 Estrogens and their receptors in breast cancer progression: a dual role in cancer proliferation and invasion. Critical Reviews in Oncology and Hematology $5155-67$.

Pons M, Gagne D, Nicolas JC \& Mehtali M 1990 A new cellular model of response to estrogens: a bioluminescent test to characterize (anti) estrogen molecules. Biotechniques 9 450-459.

Pratt WB, Galigniana MD, Harrell JM \& DeFranco DB 2004 Role of hsp90 and the hsp90-binding immunophilins in signalling protein movement. Cellular Signalling 16 857-872.

Qiu M, Olsen A, Faivre E, Horwitz KB \& Lange CA 2003 Mitogenactivated protein kinase regulates nuclear association of human progesterone receptors. Molecular Endocrinology 17 628-642.
Saporita AJ, Zhang Q, Navai N, Dincer Z, Hahn J, Cai X \& Wang Z 2003 Identification and characterization of a ligand-regulated nuclear export signal in androgen receptor. Journal of Biological Chemistry 278 41998-42005.

Schafer JM, Lee E-S, Dardes RC, Bentrem D, O'Regan RM, De Los Reyes A \& Jordan VC 2001 Analysis of cross resistance of the selective estrogen receptor modulators arzoxifene (LY353831) and LY117018 in tamoxifen-stimulated breast cancer xenografts. Clinical Cancer Research 7 2505-2512.

Segars JM \& Driggers PH 2002 Estrogen action and cytoplasmic signalling cascades, Part I: membrane-associated signalling complexes. Trends in Endocrinology and Metabolism 13 349-354.

Shank LC \& Paschal BM 2005 Nuclear transport of steroid hormone receptors. Critical Reviews in Eukaryotic Gene Expression 15 49-73.

Shao W, Keeton EK, McDonnell DP \& Brown M 2004 Coactivator AIB 1 links estrogen receptor transcriptional activity and stability. PNAS 101 11599-11604.

Stenoien DL, Mancini MG, Patel K, Allegretto EA, Smith CL \& Mancini MA 2000 Subnuclear trafficking of estrogen receptoralpha and steroid receptor coactivator-1. Molecular Endocrinology 14 518-534.

Tateishi Y, Kawabe Y, Chiba T, Murata S, Ichikawa K, Murayama A, Tanaka K, Bada T, Kato S \& Yanagisawa J 2004 Ligand-dependent switching of ubiquitin-proteasome pathways for estrogen receptor. EMBO Journal 23 4813-4823.

Watson CS, Campbell CH \& Gametchu B 2002 The dynamic and elusive membrane estrogen receptor-alpha. Steroids 67 429-437.

Walther RF, Lamprecht C, Ridsdale A, Groulx I, Lee S, Lefebvre YA \& Haché RJG 2003 Nuclear export of the glucocorticoid receptor is accelerated by cell fusion-dependent release of calreticulin. Journal of Biological Chemistry 278 37858-37864.

Wijayaratne AL \& McDonnell DP 2001 The human estrogen receptoralpha is a ubiquitinated protein whose stability is affected differentially by agonists, antagonists, and selective estrogen receptor modulators. Journal of Biological Chemistry $\mathbf{2 7 6}$ 35684-35692.

Wójcik C \& DeMartino GN 2003 Intracellular localization of proteasomes. The International Journal of Biochemistry and Cell Biology 35 579-589.

White R \& Parker MG 1998 Molecular mechanisms of steroid hormone action. Endocrine-Related Cancer 5 1-14.

Zheng FZ, Wu RC, Smith CL \& O'Malley BW 2005 Rapid estrogeninduced phosphorylation of the SRC-3 coactivator occurs in an extranuclear complex containing estrogen receptor. Molecular and Cellular Biology 25 8273-8284.

Received in final form 27 April 2007

Accepted 28 May 2007

Made available online as an Accepted Preprint

30 May 2007 